\title{
SINTESIS DAN KARAKTERISASI POLIMER ALKID POLIGLISEROL BANYAK CABANG
}

\section{SYNTHESIS AND CHARACTERIZATION OF HYPERBRANCHED POL YGL YCEROL ALKYD POL YMER}

\author{
Dwinna Rahmi ${ }^{1}$, Retno Yunilawati ${ }^{1}$, Mangala Tua Marpaung ${ }^{1}$, Chicha Nuraeni ${ }^{1}$, Nur \\ Hidayati ${ }^{1}$, Emmy Ratnawati ${ }^{1}$, Arief Riyanto ${ }^{1}$, Dicky Lasenda Setiaji ${ }^{2}$, Septian \\ Nugroho $^{2}$, Jauharotul Arifah ${ }^{2}$, Martina Indri Hastuti ${ }^{2}$, Rochmi Widjajanti ${ }^{2}$ \\ ${ }^{1}$ Balai Besar Kimia dan Kemasan, Kementerian Perindustrian RI \\ Jl. Balai Kimia I Pekayon, Pasar Rebo, Jakarta Timur \\ ${ }^{2}$ Politeknik STMI Jakarta, Kementerian Perindustrian RI \\ Jl. Letjen Suprapto No.26 Cempaka Putih, Jakarta 10510 \\ E-mail: dwinna2002@yahoo.com
}

Received : 2 September 2019; revised : 3 September 2019; accepted : 20 September 2019

\begin{abstract}
ABSTRAK
SINTESIS DAN KARAKTERISASI POLIMER ALKID POLIGLISEROL BANYAK CABANG. Polimer alkid baru telah disintesis menggunakan alkid minyak rantai panjang (long oil) dan poligliserol banyak cabang. Alkid poligliserol banyak cabang/alkid HPG merupakan salah satu alkid banyak cabang (hyperbranched alkyd polimer/HBRA). Tujuan dari penelitian ini adalah melakukan sintesis dan karakterisasi $H B R A$ baru dari $H P G$. Sintesis dilakukan dengan memanaskan campuran $77 \%$ minyak kedelai dan $23 \%$ poliol (gliserol atau HPG) pada suhu $240{ }^{\circ} \mathrm{C}$ sampai dengan $250{ }^{\circ} \mathrm{C}$ selama selama 3 jam dilanjutkan dengan penambahan $23 \%$ asam phtalat atau asam maleat dan diproses pada suhu $180{ }^{\circ} \mathrm{C}-200{ }^{\circ} \mathrm{C}$ selama 3 jam. Spektrum FTIR menunjukkan munculnya gugus fungsi ester $\mathrm{C}=\mathrm{C}$ pada panjang gelombang $3050 \mathrm{~cm}^{-1}$ dan gugus $\mathrm{C}=\mathrm{O}$ pada panjang gelombang $1350 \mathrm{~cm}^{-1}-1730 \mathrm{~cm}^{-1}$. Viskositas $40{ }^{\circ} \mathrm{C}$ alkid phtalat $H P G$ adalah $1255 \mathrm{cSt}\left(\mathrm{mm}^{2} / \mathrm{s}\right)$ dan alkid phtalat gliserol adalah $1668 \mathrm{cSt}$, sedangkan viskositas produk alkid maleat tidak dilakukan karena produk berbentuk padat. Bilangan hidroksi alkid phtalat gliserol dan alkid phtalat HPG tidak berbeda signifikan. Bilangan hidroksi alkid maleat gliserol dan alkid maleat HPG berbeda signifikan karena gugus hidroksi pada poliol tidak teresterifikasi sempurna.
\end{abstract}

Kata kunci : Polimer alkid, poligliserol banyak cabang, alkid banyak cabang, gugus fungsi, bilangan hidroksi

\begin{abstract}
SYNTHESIS AND CHARACTERIZATION OF HYPERBRANCHED POLYGLYCEROL ALKYD POLYMER. A new alkyd polymer was formulated using long oil alkyd and hyperbranched polyglycerol/HPG. Hyperbranched polyglycerol alkyd/HPG alkyd is one of the hyperbranched alkyd polymer/HBRA. The purpose of this research is to synthesize and characterize of a new HBRA from HPG. HPG alkyd were synthesized by heating mixture $77 \%$ soybean oil and $23 \%$ polyol (glycerol or HPG) at $240{ }^{\circ} \mathrm{C}-250^{\circ} \mathrm{C}$ for 3 hours, then followed by addition of $23 \%$ phthalic acid or maleic acid and processed at $180^{\circ} \mathrm{C}-200^{\circ} \mathrm{C}$ for 3 hours. Infrared/FTIR spectrum shows the intensity of functional group of $C=C$ ester at a wavelength of $3050 \mathrm{~cm}^{-1}$ and the $C=O$ group at a wavelength of $1350 \mathrm{~cm}^{-1}-1730 \mathrm{~cm}^{-1}$. The viscosity of $40^{\circ} \mathrm{C}$ phthalate HPG alkyd was $1255 \mathrm{cSt}\left(\mathrm{mm}^{2} / \mathrm{s}\right)$ and the phthalate glycerol alkyd was $1668 \mathrm{cSt}$, while the viscosity of the maleic alkyd product was not performed because it was solid. The hydroxy value of phthalates glycerol alkyd and phthalates HPG alkyd were not significant different. The hydroxy value of glycerol maleic alkyd and HPG maleic alkyd were differed significantly, because the hydroxy groups in polyols were not completely esterified.
\end{abstract}

Keywords: Alkyd polimer, hyperbranched polyglycerol, hyperbranched alkyd polimer, functional groups, hydroxy value 


\section{PENDAHULUAN}

Alkid merupakan poliester yang dimodifikasi melalui ikatan tak jenuh dari minyak nabati yang dapat mengering (drying oil). Pada industri pelapis (coating) seperti cat, alkid termasuk bahan yang penting karena sumber bahan baku utamanya yaitu drying oil dapat diperbaharui. Alkid diklasifikasi berdasarkan jumlah drying oil yang digunakan yaitu short alkid dengan kandungan minyak nabati $30 \%$ sampai dengan 42\%, medium alkid dengan kandungan 43\% - 54\% drying oil, long alkid dengan kandungan drying oil 55\% - 68\% dan very long dengan drying oil diatas $68 \%$ (Alam et al. 2014). Alkid pada industri pelapis digunakan terutama pada pengecatan dekoratif pada kayu dan besi karena mempunyai daya rekat baik, lebih gloss, lentur dan tahan terhadap alkali (Carmody 1959).

Secara umum, alkid disintesis dengan cara memanaskan poliol, minyak nabati (drying oil) dan asam karboksilat pada suhu $230{ }^{\circ} \mathrm{C}-$ $280{ }^{\circ} \mathrm{C}$ secara bersamaan (Lum 1953). Poliol yang banyak dipakai adalah gliserol, minyak nabati adalah minyak kedelai sedangkan asam karboksilat yang umum adalah asam phtalat. Mekanisme reaksi diilustrasikan seperti terlihat pada Gambar 1 (Velayutham et al. 2009) (Liang et al. 2014). Akan tetapi, dalam proses reaksi tersebut alkid memiliki kelemahan yaitu daya kering membutuhkan waktu yang lama yaitu mencapai lebih 1 minggu. Beberapa peneliti mencoba memperbaiki kualitas alkid dengan melakukan modifikasi bahan baku seperti memvariasikan jenis minyak nabati. Penggunaan minyak biji karet menghasilkan alkid dengan ketahanan cukup tinggi terhadap air, air asin, dan asam, tapi tidak tahan terhadap alkali (Ikhuoria, Aigbodion, and Okieimen 2004). Penggunaan minyak castor menghasilkan alkid lebih tahan terhadap asam namun pada proses sintesisnya membutuhkan tahapan yang panjang menggunakan dua jenis katalis yaitu $\mathrm{NaOH}$ dan $\mathrm{PbO}$ (Hlaing and Oo 2008). Penggunaan minyak sawit menghasilkan alkid dengan daya rekat yang lebih kuat dan sifat melindungi lebih lama walaupun waktu kering lebih lama (Issam and Cheun 2009). Selain modifikasi terhadap minyak nabati, pembuatan alkid juga dilakukan dengan memodifikasi asam karboksilatnya. Penggunaan asam isosianat sudah dilakukan tahun 1950. Alkid isosianat dengan pelarut organik mempunyai kelebihan menjadikan cat lebih mengkilat dan tahan gesekan (Axtmann 1983), namun kurang ramah lingkungan.

Pada tahun 2002, alkid dengan struktur banyak cabang (hyperbranched alkyd polimerl HBRA) mulai dikenalkan. Alkid HBRA dapat berwujud padat maupun cair tergantung bahan yang digunakan. Alkid HBRA padat dihasilkan dengan asam karboksilat trimethylpropane dan dimethylolpropionic acid.

Penggunaan alkid $H B R A$ pada formula cat menghasilkan cat yang lebih lembut, cepat mengering serta dapat mengurangi penggunaan pelarut organik (K. Mańczyk and Szewczyk 2002). Penggunaan hydroxylates hyperbranched menghasilkan alkid HBRA dengan daya kilap (gloss) dan daya rekat lebih tinggi dan juga lebih fleksibel, waktu kering cepat, dan tahan terhadap bahan kimia (Murillo, Vallejo, and López 2010). Daya kilap dan daya kering lebih tinggi pada $H B R A$ karena adanya rantai cabang yang menjadikan viskositanya lebih rendah walaupun berat molekul sama dengan rantai linear (Lindeboom 1997). Kombinasi butylmetacrylate dengan maleic anyidrida juga menghasilkan alkid yang lebih fleksibel, daya kilap tinggi, tahan terhadap bahan kimia juga lebih keras (Murillo and López 2011). Akan tetapi modifikasi poliol banyak cabang belum banyak dikembangkan.

Pada penelitian ini akan dikembangkan HBRA menggunakan poliol banyak cabang (hyperbranched polyglycerol/HPG).

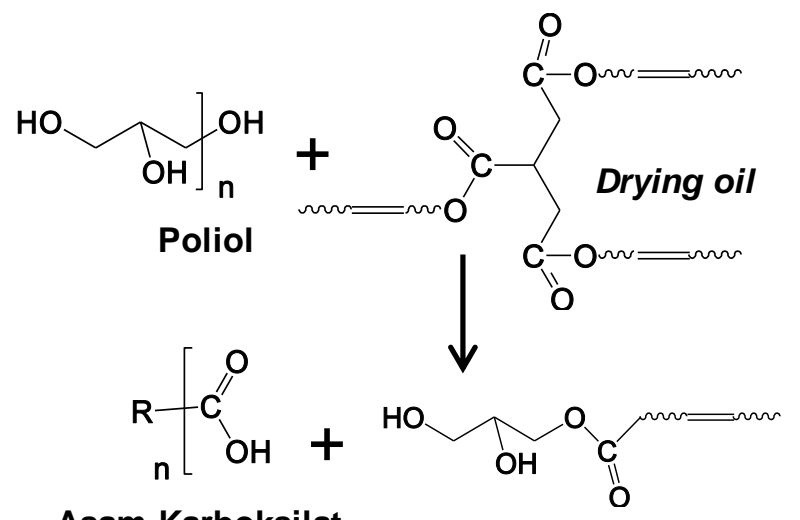

Asam Karboksilat

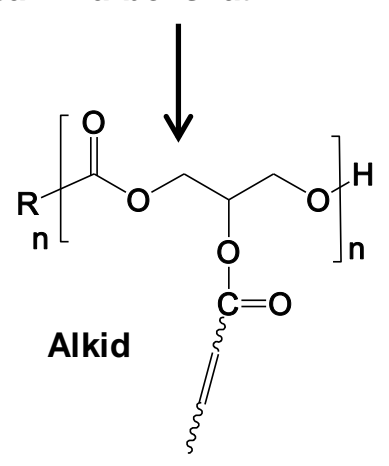

Monogliserida

Gambar 1. Reaksi poliol, drying oil, asam karboksialat menghasilkan alkid

HPG merupakan salah satu polimer banyak cabang yang disintesis dengan proses polimerisasi gliserol (Ciriminna and Pagliaro 
2013). Selama ini HPG digunakan dalam bidang farmasi sebagai pengantar obat (Boudou et al. 2013), sebagai perekat kayu (Mamiński et al. 2013), sebagai salut katalis (Lang et al. 2003) (Rahmi, Yunilawati, and Riyanto 2016). Pada penelitian ini HPG dikembangkan menjadi polimer alkid.

Tujuan penelitian ini adalah melakukan sintesis alkid dengan menggunakan HPG sebagai poliol untuk menghasilkan alkid dengan viskositas lebih rendah. HPG merupakan polimer banyak cabang yang disintesa dari gliserol turunan kelapa sawit yang merupakan bahan yang dapat diperbaharui dan lebih ramah lingkungan.

\section{BAHAN DAN METODE}

\section{Bahan dan Alat}

Gliserol diperoleh dari PT. Wilmar Nabati, $\mathrm{CaO}$ alam dari PT. Sari Bumi Sidayu, minyak kedelai produksi PT. Kimia Farma. Asam phtalat dan asam maleat dari PT. Merck. Ethanol yang digunakan untuk uji performa adalah ethanol teknis dari Bratachem. Adapun alat yang digunakan untuk proses polimerisasi gliserol dan sintesis polimer alkid adalah reaktor tertutup merk PARR yang dilengkapi dengan pengaduk, pemanas dan aliran gas nitrogen. Timbangan dan alat gelas lainnya juga digunakan dalam preparasi sampel.

\section{Sintesis Alkid}

HPG diproses dengan memanaskan gliserol pada suhu $240{ }^{\circ} \mathrm{C}-250{ }^{\circ} \mathrm{C}$ dengan penambahan katalis $\mathrm{CaO}$ selama 20 jam. Selama pemanasan, bahan diaduk dengan kecepatan 100 rpm pada reaktor tertutup (Rahmi, Yunilawati, and Riyanto 2016). Produk HPG lalu dipakai pada proses pembuatan alkid.

Sintesis alkid dilakukan dalam dua tahap yaitu proses alkoholisis dan esterifikasi. Pada proses alkoholisis minyak kedelai direaksikan dengan poliol yaitu gliserol atau poligliserol menghasilkan produk alkohol. Selanjutnya dilakukan proses esterifikasi (Krzysztof Mańczyk and Szewczyk 2002) dengan cara mereaksikan produk monogliserida dengan asam karboksilat yaitu asam phtalat atau asam maleat. Proses dilakukan tanpa penambahan katalis.

Minyak kedelai, HPG, asam phtalat atau asam maleat berturut-turut dengan perbandingan berat $77 \%, 23 \%$, dan $23 \%$ disiapkan pada tempat terpisah. Masukkan minyak kedelai dan poliol kedalam reaktor lalu ditutup. Alirkan gas nitrogen sambil diaduk dengan kecepatan $100 \mathrm{rpm}$. Panaskan reaktor pada suhu $240{ }^{\circ} \mathrm{C}-250{ }^{\circ} \mathrm{C}$ selama 1 jam - 4 jam. Dinginkan reaktor lalu lanjutkan dengan proses esterifikasi dengan penambahan asam phtalat atau asam maleat kedalam reaktor. Panaskan reaktor pada suhu $180{ }^{\circ} \mathrm{C}-200{ }^{\circ} \mathrm{C}$ selama 1 jam
- 4 jam. Alirkan produk samping berupa air keluar reaktor. Lalu ambil produk alkid untuk dilakukan analisa.

\section{Karakterisasi}

Karakteristik produk hasil proses alkoholisis dilakukan dengan cara melihat larut atau tidak larutnya produk di dalam alkohol (etanol/methanol) (Hlaing and Oo 2008). Penentuannya dengan cara menempatkan 1 gram produk ke dalam gelas piala, lalu masukkan etanol sebanyak $5 \mathrm{~mL}$. Selanjutnya diaduk (stirrer) selama 5 menit lalu produk diamati kelarutannya dengan melihat sudah menyatu atau masih ada pemisahan.

Pengujian gugus fungsi produk alkid dilakukan dengan FTIR Spectrometer merek Nicolet IS 5 Thermo Fisher Scientific. Karakterisasi produk alkid dilakukan dengan menguji bilangan hidroksi berdasarkan ASTM E 222 (2017) serta viskositas $40{ }^{\circ} \mathrm{C}$ sesuai ASTM D445-17a (2017).

\section{HASIL DAN PEMBAHASAN}

\section{Pengaruh waktu proses terhadap performan produk alkid}

Pada proses alkoholisis, drying oil yaitu minyak nabati dan poliol dipanaskan pada suhu $240{ }^{\circ} \mathrm{C}-250{ }^{\circ} \mathrm{C}$ dengan kecepatan aduk 100 rpm selama variasi waktu 1 jam, 2 jam, 3 jam, dan 4 jam. Proses alkoholisis menghasilkan monogliserida (Gambar 2) (Prakoso 2016) yang larut didalam alkohol. Penentuan sudah terbentuknya produk monogliserida adalah dengan melihat kelarutan produk di dalam alkohol, dalam penelitian ini alkohol yang digunakan adalah ethanol. Kelarutan produk monogliserida dalam ethanol dapat dilihat pada Tabel 1. Produk yang dihasilkan dengan waktu proses alkoholisis selama 1 jam dan 2 jam menghasilkan produk yang belum larut di dalam ethanol, hal ini diketahui dengan masih terlihat adanya pemisahan antara produk dan ethanol. Produk yang larut sempurna di dalam ethanol menandakan reaksi alkoholisis sudah sempurna (Hlaing and Oo 2008). Produk yang dihasilkan dengan waktu proses selama 3 jam dan 4 jam juga larut sempurna dalam ethanol. Dari hasil ini didapatkan waktu proses alkoholisis adalah 3 jam atau 4 jam. Namun, dari penampakan/warna produk terlihat ada perbedaan. Produk yang dihasilkan dengan waktu proses 3 jam bewarna kuning bening, sedangkan produk yang diproses 4 jam bewarna lebih coklat. Hal ini kemungkinan terjadinya oksidasi sehingga meningkatkan bilangan peroksida yang mengakibatkan perubahan warna menjadi lebih gelap. Berbeda dengan waktu proses alkoholisis minyak castor dan gliserol dengan penambahan katalis $\mathrm{PbO}$ komplit membutuhkan waktu 4 jam untuk 
menghasilkan produk yang larut dalam alkohol (Hlaing and Oo 2008).

Proses esterifikasi monogliserida dengan asam karboksilat (asam phtalat atau asam maleat) mengacu pada Gambar 1 menghasilkan phtalat alkid atau maleat alkid. Phtalat alkid dan maleat alkid diilustrasikan pada Gambar 2.

Proses esterifikasi pada penelitian ini dilakukan dengan variabel waktu 1 jam, 2 jam, 3 jam, dan 4 jam pada suhu proses $180{ }^{\circ} \mathrm{C}-200$ ${ }^{\circ} \mathrm{C}$ dan kecepatan aduk $100 \mathrm{rpm}$ menghasilkan produk alkid. Hasilnya dapat dilihat pada Tabel 1, alkid phtalat yang dihasikan dari proses esterifikasi selama 1 jam dan 2 jam menghasilkan alkid berbentuk larutan dan padatan.

Alkid phtalat yang diproses selama 3 jam dan 4 jam menghasilkan alkid berbentuk cairan. Namun, warna alkid phtalat yang dihasilkan pada proses selama 4 jam berwarna lebih gelap dibanding alkid phtalat yang dihasilkan selama 3 jam proses. Alkid maleat yang dihasilkan dari proses esterifiksi selama 1 jam sampai 4 jam menghasilkan produk masih berbentuk padat, ini menandakan pembentukan alkid belum sempurna (Hlaing and Oo 2008). Bentuk padat pada produk alkid maleat merupakan bahan maleat yang belum bereaksi dengan minyak kedelei.

Suhu dan waktu proses sangat mempengaruhi terbentuknya alkid. Suhu proses tetap $180{ }^{\circ} \mathrm{C}$ dengan kondisi vakum dan waktu yang lebih lama kemungkinan akan menghasilkan alkid yang lebih sempurna (Budiman 2011). Bila dilihat pengaruh waktu proses terhadap bilangan hidroksi, terlihat jelas waktu proses mempengaruhi bilangan hidroksi. Waktu reaksi yang terlalu lama akan menurunkan bilangan hidroksi. Lamanya waktu proses menyebabkan tenaga kinetik molekulmolekul zat pereaksi yaitu asam karboksilat semakin besar sehingga kesempatan reaktan saling bertumbukan semakin besar (Abdullah 2012). Hal ini yang menyebabkan berubahnya warna alkid dari krem menjadi coklat.

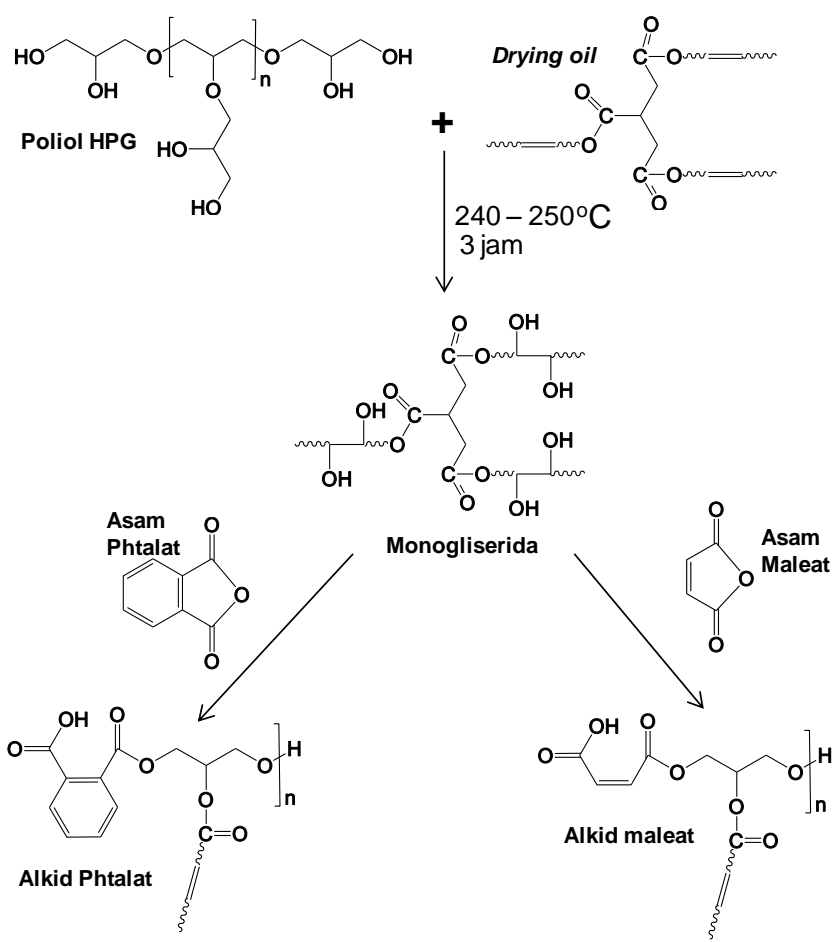

Gambar 2. Skematik sintesis alkid HPG

Tabel 1. Pengaruh waktu proses terhadap produk alkohol

\begin{tabular}{ccc}
\hline Waktu proses / jam & $\begin{array}{c}\text { Kelarutan dalam } \\
\text { etanol/methanol }\end{array}$ & Keterangan \\
\hline 1 & Ada pemisahan & Larutan bening kekuningan \\
2 & Ada pemisahan & Larutan bening kekuningan \\
3 & Larut & Larutan bening kekuningan \\
4 & Larut & Larutan coklat \\
\hline
\end{tabular}




\section{Spektrum Infrared Alkid}

Pengukuran gugus fungsi dengan FTIR dilakukan untuk melihat gugus yang ada pada produk alkid yang dihasilkan. Gambar 3 memperlihatkan spektrum kromatografi asam phtalat, asam maleat, HPG, alkid phtalat gliserol, alkid maleat gliserol, alkid phtalat $H P G$, dan alkid maleat $H P G$.

Gambar 3a terlihat spektrum asam phtalat, HPG, alkid gliserol, alkid HPG. Spektrum dengan panjang gelombang $3550 \mathrm{~cm}^{-1}$ mengindikasikan gugus hidroksi $\mathrm{OH}$. Gugus $\mathrm{OH}$ ini terlihat besar pada HPG dan tidak terlihat pada asam phtalat. HPG merupakan poliol dengan gugus $\mathrm{OH}$ lebih banyak dibanding gliserol (Rahmi, Yunilawati, and Riyanto 2016). Gugus $\mathrm{OH}$ pada alkid terlihat lebih kecil, sedangkan gugus $\mathrm{OH}$ pada asam phtalat tidak ada dan pada asam maleat ada sedikit (ada dua gugus $\mathrm{OH}$ pada struktur asam meleat).
Spektrum yang keluar pada panjang gelombang $3050 \mathrm{~cm}^{-1}$ mengindikasikan gugus $\mathrm{C}=\mathrm{C}$. Gugus $\mathrm{C}=\mathrm{C}$ terlihat muncul pada produk alkid dan tidak ada pada bahan baku seperti terlihat pada skematik struktur alkid phtalat dan alkid maleat di Gambar 2. Gugus OH pada HPG bereaksi menghasilkan gugus $\mathrm{C}=\mathrm{C}$ dan menambah gugus $\mathrm{C}=\mathrm{O}$ pada panjang gelombang $1350 \mathrm{~cm}^{-1}$ - $1730 \mathrm{~cm}^{-1}$, mengakibatkan bilangan hidroksi berkurang. Gugus $\mathrm{C}=\mathrm{O}$ pada produk alkid menandakan sudah terbentuknya produk ester. Gugus ester ini yang menentukan bahwa produk alkid sudah terbentuk. Selain itu pola gugus $\mathrm{C}-\mathrm{H}$ pada alkid terlihat lebih tajam dibanding pada HPG. Pola spektrum FTIR yang sama juga terlihat pada alkid HBRA hydroxylated hyperbranched polyester 2,2bis(hydroxymethyl)propanoic acid dan pentaerythritol (Murillo, Vallejo, and López 2010). a)

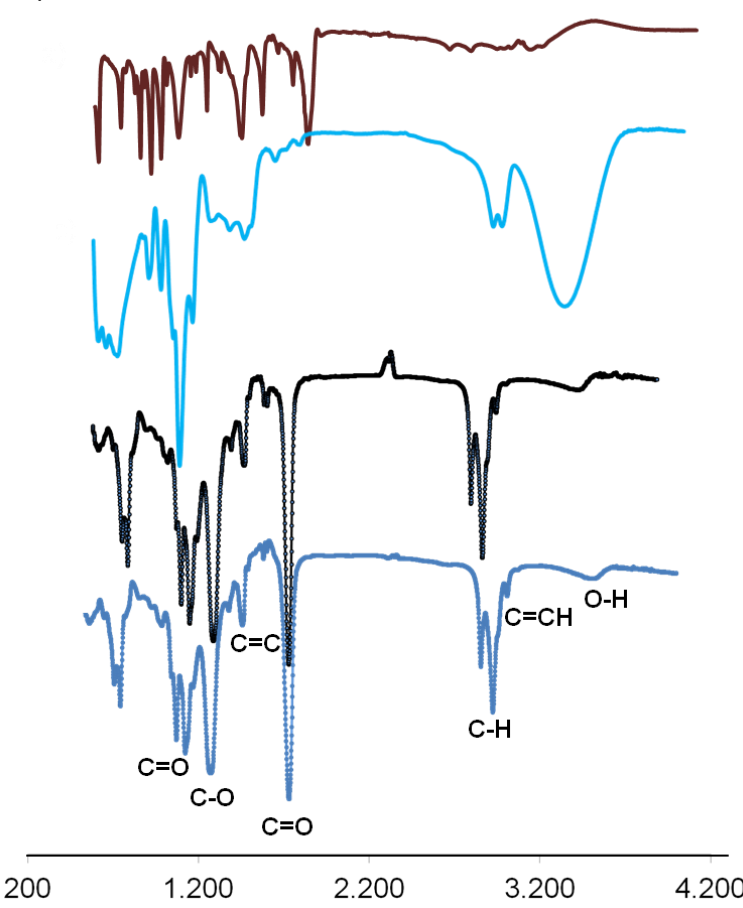

b)

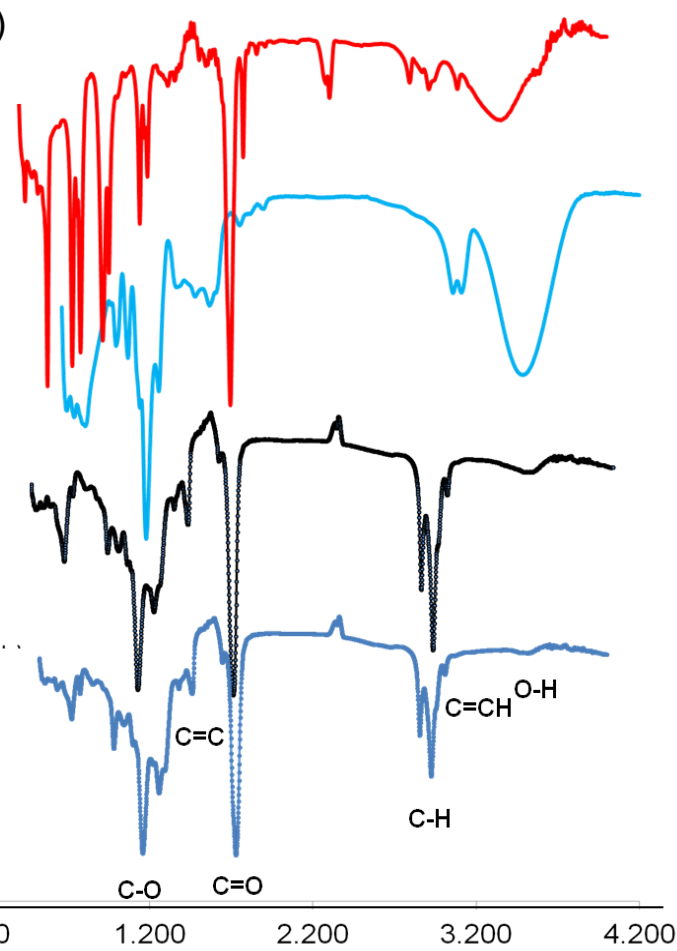

Gambar 3. Spektrum kromatograpi FTIR a) asam phtalat, HPG, alkid phtalat gliserol, alkid phtalat $H P G$ b) asam maleat, $H P G$, alkid maleat gliserol, alkid maleat $H P G$.

Tabel 2. Viskositas dan Bilangan Hidroksi Alkid

\begin{tabular}{ccc}
\hline Nama & Viskositas $40{ }^{\circ} \mathrm{C} / \mathrm{cSt}$ & Bilangan Hidroksi \\
\hline Alkid phtalat gliserol & 1668 & 130 \\
Alkid phtalat $H P G$ & 1255 & 129 \\
Alkid maleat gliserol & - & 91 \\
Alkid maleat $H P G$ & - & 176 \\
\hline
\end{tabular}




\section{Karakteristik polimer alkid}

Karakteristik polimer ditentukan dengan melihat viskosits $40{ }^{\circ} \mathrm{C}$ yang dikenal dengan viskositas dinamis dan bilangan hidroksi. Viskositas merupakan ukuran yang menyatakan kekentalan dari suatu cairan atau fluida. Viskosits diperlukan untuk mengetahui berapa daya tahan dari aliran yang diberikan kepada suatu cairan. Pada alkid, viskositas diperlukan untuk pemakaian nantinya pada formula coating. Pada Tabel 2 ditampilkan viskosits dari alkid phtalat, sedangkan viskositas alkid maleat tidak diukur karena produk yang terbentuk masih ada yang berbentuk padatan. Viskositas alkid phtalat gliserol lebih tinggi dari viskositas alkid phtalat HPG. HPG dengan struktur rantai bercabang (Gambar 2) mempunyai viskositas lebih rendah. Ini menandakan struktur cabang dari alkid HPG lebih banyak dari alkid gliserol. Sama halnya dengan viskositas alkid HBRA trimethylolpropane relatif lebih rendah (K. Mańczyk and Szewczyk 2002).

Bilangan hidroksi pada polimer alkid dilakukan dengan mengukur gugus hidroksi bebas dalam polimer alkid. Pada Tabel 3 dapat dilihat bilangan hidroksi alkid phtalat HPG dan alkid phtalat gliserol tidak berbeda signifikan. Sebaliknya, bilangan hidroksi alkid maleat HPG lebih tinggi signifikan dari alkid maleat gliserol. Hal ini menandakan bahwa kandungan gugus hidroksi bebas pada alkid maleat HPG lebih banyak dari kandungan gugus hidroksi bebas alkid maleat gliserol. Kandungan hidroksi bebas pada alkid maleat HPG berasal dari gugus hidroksi HPG yang belum teresterifikasi atau reaksi belum sempurna. Hasil ini menandakan bahwa proses esterifikasi pada monogliserida dengan asam maleat belum sempurna. Banyaknya gugus hidroksi pada phtalat menghasilkan tingginya bilangan hidroksi alkid phtalat gliserol dari bilangan hidroksi alkid maleat gliserol.

\section{KESIMPULAN}

Polimer alkid dapat disintesis melalui proses alkoholisis dan esterifikasi minyak nabati dengan poliol dan asam karboksilat. Proses alkoholisis minyak nabati dan poliol (gliserol dan HPG) pada suhu $240{ }^{\circ} \mathrm{C}-250^{\circ} \mathrm{C}$ selama 3 jam dan dilanjutkan dengan proses esterifikasi dengan penambahan asam phtalat atau asam maleat pada suhu $180{ }^{\circ} \mathrm{C}-200{ }^{\circ} \mathrm{C}$ selama 3 jam menghasilan produk alkid berwarna lebih terang dibandingkan bila diproses selama 4 jam. Terbentuknya alkid ditandai dengan munculnya gugus $\mathrm{C}=\mathrm{C}$ dan gugus ester $\mathrm{C}=\mathrm{O}$ pada spektrum kromatografi FTIR. Viskositas alkid HPG lebih rendah dibanding viskositas alkid gliserol. Pada penelitian ini, bilangan hidroksi alkid phtalat HPG dan alkid phtalat gliserol tidak berbeda signifikan. Bilangan hidroksi alkid maleat $H P G$ lebih tinggi hampir tiga kali lipat dari alkid maleat gliserol yang menandakan proses esterifikasinya belum sempurna sehingga perlu dilakukan optimalisasi.

\section{DAFTAR PUSTAKA}

Abdullah, S. 2012. "Pengaruh Waktu Reaksi Terhadap Bilangan Hidroksil Pada Pembentukan Polyol Dari Epoksidasi CPO Dan Curcas Oil." Konversi 1 (1): 15-24.

Alam, M., D. Akram, E. Sharmin, F. Zafar, and S. Ahmad. 2014. "Vegetable Oil Based EcoFriendly Coating Materials: A Review Article." Arabian Journal of Chemistry 7 (4). King Saud University: 469-79. doi:10.1016/j.arabjc.2013.12.023.

ASTM D445 - 17a. 2017. "Standard Test Method for Kinematic Viscosity of Transparent and Opaque Liquids (and Calculation of Dynamic Viscosity)."

ASTM E222 - 17. 2017. "Standard Test Methods for Hydroxyl Groups Using Acetic Anhydride Acetylation."

Axtmann, R.C. 1983. Desilication Of Geothermal Water. US4378295A, issued 1983. doi:10.1016/0375-6505(85)90011-2.

Boudou, J. Paul, M. O. David, V. Joshi, H. Eidi, and P. A. Curmi. 2013. "Hyperbranched Polyglycerol Modified Fluorescent Nanodiamond for Biomedical Research." Diamond and Related Materials 38. Elsevier B.V.: 131-38. doi:10.1016/j.diamond.2013.06.019.

Budiman, A. 2011. "Pengaruh Suhu Reaksi Alkoholisis Terhadap Derajat Polimerisasi Alkyd Resin Termodifikasi Minyak Jagung," 1-6.

Carmody, R.F. 1959. Mixed resinous esters of oil-modified alkyd resins and of partiallyesterified epoxide resins. US2887459A, issued 1959.

Ciriminna, R., and M. Pagliaro. 2013. Method for the production of hyperbranched polyglycerol. European Patent, issued 2013. doi:10.1210/jc.2004-1149.

Hlaing, N.N., and M.M. Oo. 2008. "Manufacture of Alkyd Resin from Castor Oil." World Academy of Science, Engineering and Technology 48: 155-61.

Ikhuoria, E.U., A.I. Aigbodion, and F.E. Okieimen. 2004. "Enhancing the Quality of Alkyd Resins Using Methyl Esters of Rubber Seed Oil." Tropical Journal of Pharmaceutical Research 3 (June): 31117.

Issam, A. M., and C. Y. Cheun. 2009. "A Study of the Effect of Palm Oil on the Properties of a New Alkyd Resin" 4 (1): 42-49.

Lang, H, R. A. May, B. L. Iversen, and B. D. Chandler. 2003. "Dendrimer- Encapsulated 
Nanoparticle Precursors to Supported Platinum Catalysts." J. Am. Chem. Soc. 125: 14832-36.

Liang, L., C. Liu, X. Xiao, S. Chen, A. Hu, and J. Feng. 2014. "Progress in Organic Coatings Optimized Synthesis and Properties of Surfactant-Free Water-Reducible AcrylateAlkyd Resin Emulsion." Progress in Organic Coatings 77 (11). Elsevier B.V.: 1715-23. doi:10.1016/j.porgcoat.2014.05.015.

Lindeboom, J. 1997. "Air-Drying High Solids Alkyd Pants for Decorative Coatings." Progress in Organic Coatings 34 (1-4): 147-51. doi:10.1016/S03009440(98)00034-4.

Lum, F. G. 1953. Long oil alkyd resins. US2627508A, issued 1953.

Mamiński, M., S. Witek, K. Szymona, and P. Parzuchowski. 2013. "Novel Adhesive System Based on 1,3-Dimethylol-4,5Dihydroxyethyleneurea (DMDHEU) and Hyperbranched Polyglycerols." European Journal of Wood and Wood Products 71 (2): 267-75. doi:10.1007/s00107-0130680-9.

Mańczyk, K., and P. Szewczyk. 2002. "Highly Branched High Solids Alkyd Resins." Progress in Organic Coatings 44 (2): 99109. doi:10.1016/S0300-9440(01)00249-1.

Mańczyk, K., and Pawel Szewczyk. 2002.
"Highly Branched High Solids Alkyd Resins." Progress in Organic Coatings 44 (2): 99-109. doi:10.1016/S03009440(01)00249-1.

Murillo, E. A., and B. L. López. 2011. "Progress in Organic Coatings Novel Waterborne Hyperbranched Acrylated-Maleinized Alkyd Resins." Progress in Organic Coatings 72 (4). Elsevier B.V.: 731-38. doi:10.1016/j.porgcoat.2011.08.004.

Murillo, E. A., P. P. Vallejo, and B. L. López. 2010. "Synthesis and Characterization of Hyperbranched Alkyd Resins Based on Tall Oil Fatty Acids." Progress in Organic Coatings 69 (3). Elsevier B.V.: 235-40. doi:10.1016/j.porgcoat.2010.04.018.

Prakoso, T. 2016. "Pembuatan Monogliserida," no. December 2007.

Rahmi, D., R. Yunilawati, and A. Riyanto. 2016. "Sintesis Katalis Logam Berpenyangga Dendrimer Poligliserol Berbasis Turunan Kelapa Sawit." Jurnal Kimia Dan Kemasan 38 (2): 61. doi:10.24817/jkk.v38i2.2225.

Velayutham, T. S., W. H. Abd Majid, A. B. Ahmad, G. Yik, and S. N. Gan. 2009. "Progress in Organic Coatings Synthesis and Characterization of Polyurethane Coatings Derived from Polyols Synthesized with Glycerol , Phthalic Anhydride and Oleic Acid" 66: 367-71. doi:10.1016/j.porgcoat.2009.08.013. 